\title{
Comparative determination of digestibility and energy contents of heliz and parzuk with traditional forages by in vivo and in vitro methods*
}

\author{
Research Article \\ Volume: 2, Issue: 2 \\ August 2018 \\ Pages: 47-52
}

\section{Article History}

Received: 28.05.2018

Accepted: 10.07.2018

Available online:

11.07.2018

\section{Mahmut Ekinci' ${ }^{1}$, Suphi Deniz ${ }^{2}$, Selçuk Altaçlı}

1.Project Monitoring and Evaluation Center, Governorship Gürpınar, Van, Turkey

2.Department of Animal Nutrition and Nutritional Diseases, Faculty of Veterinary Medicine, Yuzuncu Yil University, Van, Turkey.

*A part of this study was presented as a oral presentation at the VI National Animal Nutrition Congress, 29 June- 2 July 2011, Samsun, Turkey.

\begin{abstract}
The aim of this study was to determine digestibility and energy contents of plants heliz (Prangos pabularia) and parzuk (Hippomarathrum microcarpum) with in vivo and in vitro methods and also to compare them to traditional. Seven male Red Karaman hoggets were used in the trial. Digestibilities of four different forages were determined with classical and two-stage digestibility methods. Moreover, energy contents of forages were also estimated using both digestibility values. In situ degradation characteristics of these forages were also evaluated. In the in vivo trial for digestibility, the degrees of digestibility of four different forage plants were determined by "missing block trial pattern". In vivo organic matter digestibility (OMD) of parzuk and heliz (75.52\% and $73.46 \%)$ were higher than those of dried meadow grass (68.94\%) and dried alfalfa hays $(65.81 \%),(P<0.05)$. These difference were reflected in energy contents and DE (digestible energy) (3.33 and 3.24Mcal/kg dry matter (DM)), ME (2.73 and $2.65 \mathrm{Mcal} / \mathrm{kg}$ ) and NEL (net energy lactation) (1.73 and $1.68 \mathrm{Mcal} / \mathrm{kg} \mathrm{DM})$ values of parzuk and heliz were higher than those of meadow grass $(3.04,2.49$ and $1.57 \mathrm{Mcal} / \mathrm{kg} \mathrm{DM})$ and dried alfalfa $(2.90,2.38$ and $1.49 \mathrm{Mcal} / \mathrm{kg}$ DM) hays, $(P<0.05)$. In the two-stage digestibility method, OMD values were $71.88,68.85,66.99$ and $58.52 \%$ for parzuk, heliz, meadow grass hay and dried alfalfa hay, respectively $(P<0.05)$ The highest OMD was observed in parzuk with two-stage digestibility method, while OMD of heliz and dried meadow grass were similar to that of parzuk, OMD of dried alfalfa was similar to that of dried meadow grass but less than those of parzuk and heliz $(P<0.05)$. In in situ experiment, degradability of dried alfalfa, parzuk and heliz were rapid after 4 hours incubation but degradability of meadow grass hay were slow. Dry matter digestibility of meadow grass hay, dried alfalfa hay, parzuk and heliz was $72.45,76.36,88.36$ and $84.21 \%$, respectively at end of 48 hours incubation period $(\mathrm{P}<0.05)$. In conclusion, parzuk and heliz grown at highlands, in case of cultivation, these plants can be alternative forages to other high quality forages such as alfalfa hay.
\end{abstract}

Keywords: dried meadow hay, dried alfalfa, parzuk, heliz, in vivo/in vitro

DOI: $10.30704 /$ http-www-jivs-net.427603

To cite this article: Ekinci, M., Deniz, S. \& Altaçlı, S. (2018). Comparative determination of digestibility and energy contents of heliz and parzuk with traditional forages by in vivo and in vitro methods. Journal of Istanbul Veterinary Sciences, 2(2), 47-52. Abbreviated Title: J Ist Vet Sci

\section{Introduction}

Prangos pabularia and Hippomarathrum microcarpum, which grow widely in the high plateaus of the East Anatolia Region and are used by the local people to feed their sheep, have a considerable potential in meeting the high-quality forage requirements of livestock in the region. It is important to determine the nutrient contents of these plants, present their consumption by livestock and their availability, and to increase their production by cultivation. Belonging to 
the family Apiaceae, these plants grow naturally in many parts of the world, including the Balkans, Sicily, the Caucasus and Iran. In Turkey, it grows in high regions at an altitude of 1,000 to $2,800 \mathrm{~m}$, such as Kastamonu, Giresun, Kars, Erzurum, Ağrı, Konya, Kahramanmaraş and Hakkari. It is a perennial plant with a height of 50 to $150 \mathrm{~cm}$ (Davis, 1972). In a study conducted in Iran by Eilami and Noroozian (1995), it is reported that the replacement of dried alfalfa, which constitutes $60 \%$ of the ration for Karakul lambs, with this plant at a ratio of $12 \%, 24 \%, 48 \%$ and $60 \%$ does not affect the fattening performance and carcass quality. In a study conducted by Coşkun et al. (2005) to find the chemical composition and nutritional value of Prangos ferulacea, the metabolic energy value of the plant is reported to be $12.2 \mathrm{Mj} / \mathrm{kg} \mathrm{DM}$. In a study conducted by Önal et al. (2004) to research the effect of Ferula communis on the reproductive functions of hoggets, it was reported that the estrogen content of this plant has a positive impact on the reproductive yield of livestock. Alfalfa is called the queen of the forage plants because it contains many basic and active nutrients. In Turkey, alfalfa is mainly used as a dried fodder in the nutrition of livestock (Çerçi et al., 2011).

The purpose of this study is to determine, through in vivo and in vitro methods, the digestibility and energy contents of P. pabularia and H. microcarpum, which grow widely on the high plateaus of the East Anatolia Region and are used by the local people to feed their sheep, and to compare them with the traditional forage (meadow grass and dried alfalfa) commonly used in the region.

\section{Materials and methods}

The dried meadow grass and dried alfalfa used in the trial was procured from Van. H. microcarpum and P. pabularia were obtained from Gevaş, Van and Hakkari. In the in vivo trial for digestibility, the degrees of digestibility of four different forage plants were determined by "missing block trial pattern" (Düzgüneş et al., 1983). Seven male Red Karaman hoggets at one year of age were used in the trial. The DE, ME and NEL contents of the forage were calculated on the basis of the crude nutrient digestibility of the forage (Van ES, 1978; MAFF, 1975; Öğretmen and Kılıç, 1991).

To this end, seven cages were used in the experiment that were produced specifically for digestion experiments in a special workshop, containing portable mangers and water bowls on the front side, suitable for placement of sheep and goats.
For the collection of fertilizer in the experiment, we used a polyester tent fabric measuring $25 \times 40 \mathrm{~cm}$ with bonding belts on four sides, one-side zippered fertilizer pouches that were specially sewed, and belts resembling horse harness that were fixed to the animals. All of the animal manure was collected.

For the purpose of the study, a 10-day preexercise period was applied to allow the animals to adapt to the cage environment and trial feeds, and to determine feed consumption. Throughout the following 10-day main exercise period, the animals were fed different roughages in amounts that they could fully consume.

Each experiment period was arranged as 10 days of exercise and seven days of sample collection. The amount of feed given to the animals in two meals was arranged to be around 90 percent of their ad libitum consumption. Attention was paid to meeting the nutritional needs for the survival of the animals (NRC, 1985).

During the sample collection periods, the fertilizer was emptied from the fertilizer bags and weighed separately at the same time each day, and 10 percent of the material was deep frozen for later analysis. At the end of each period, the specimens of each animal were combined and mixed homogeneously, and after the amount required for the crude protein analysis was separated, the remaining fertilizer was dried using the method reported by Bratzler and Swift (1959).

In the in vitro trial, the version modified by Marten and Barnes (1980) of the two-stage digestion method reported by Tilley and Terry (1963) was employed. DE, ME and NEL contents of the forage were calculated on the basis of the organic matter digestibility of the forage (NRC, 1989; Ishler et al., 2000).

In the first step, in two repetitions from each feed sample, $0.25 \mathrm{~g}$ feed samples were weighed into $50 \mathrm{~mL}$ centrifuge tubes, and $25 \mathrm{~mL}$ of a buffer solution filled with $\mathrm{CO}_{2}$ gas, along with $5 \mathrm{~mL}$ of rumen fluid in a $\mathrm{CO}_{2}$ gas medium were added. The tubes were then closed with special caps containing injector needles to allow gas to be discharged from the tubes, and the tubes were left in a water bath at $38^{\circ} \mathrm{C}$ for 48 hours of incubation. During the incubation period, the caps on the tubes were opened and $1 \mathrm{~mL}$ of $5 \% \mathrm{HgCl}_{2}$ solution was added to each tube, and centrifuged for 15 minutes at 2500-3000 rpm/min, after which, the clear liquid layer over the sedimentation was removed.

In the second step, $25 \mathrm{~mL}$ of a $0.2 \%$ pepsin $+\mathrm{HCL}$ solution was added to each tube, and the tubes were 
left for incubation for 24 hours in a water bath at $38^{\circ}$ C. At the end of the incubation period, the tubes were filtered through Gooch crucibles, of which the tare weight had been determined beforehand. They were then dried at $105^{\circ} \mathrm{C}$, weighed and then burned for eight hours in an ash oven at $550^{\circ} \mathrm{C}$. Calculations were made after the burnt samples were cooled and weighed again.

Using the nylon bag technique, the characteristics regarding the rumen degradability of the forage plants were explored. For this purpose, the rumen degradation of dried meadow grass, dried alfalfa, $\mathrm{H}$. microcarpum and P. pabularia in 4, 8, 16, 24 and 48 hours were determined (Deniz and Tuncer, 1995). In the trial, two White Karaman rams at three years of age, which had rumen fistula, were used. The animals were fed with sainfoin throughout the trial.

For this purpose, each feed sample was applied in two repetitions for each animal. The samples of the used feed materials were ground to a $2 \mathrm{~mm}$ size and placed in pouches after weighing. The nylon pouches were washed in a mini washing machine for 15 minutes after each usage, and then dried in a drying cabinet at $80^{\circ} \mathrm{C}$ for 24 hours. The tare weight of the pouches were determined after cooling in a desiccator.

Approximately $3 \mathrm{~g}$ of feed sample was placed in the pouches, of which the tare weights had been determined, and the pouches were tied tightly with rubber band. Then, the pouches were attached to thin plastic hoses measuring $25 \mathrm{~cm}$ in length and perforated at even intervals using $20 \mathrm{~cm}$ nylon thread. The pouches were left in the rumen in a way that one end of the plastic hose remained in the fistula cover.

At the end of the incubation periods, the pouches collected from the rumen were rinsed with tap water to remove coarse dirt, and then washed in a mini washing machine for 15 minutes and left to dry at $80^{\circ}$ $\mathrm{C}$ for 24 hours. The pouches taken from the drying cabinet were cooled in a desiccator, and their weights were recorded (Deniz and Tuncer, 1995).

Variance analysis was employed to statistically assess the data obtained from the study. Duncan's multiple comparison test was used to determine the differences between the groups (Steel and Torrie, 1980). The calculations were made using the SPSS 17.0 package program.

\section{Results and Discussion}

The ratio of OM was found to be lower than other forage because the DM contents of the forage used in this study are similar, but the ratio of ash in dried alfalfa is high (Table 1). The crude protein (CP) content of $\mathrm{H}$. microcarpum and P. pabularia are similar to the CP contents of dried meadow grass, whereas their neutral detergent fiber (NDF) and acid detergent fiber (ADF) content are lower than those in dried meadow grass and dried alfalfa. As the harvest period of forage directly affects its nutrient content, it would not be appropriate to make a general judgment based on a single forage sample. For this reason, the assessments made regarding the nutrient content of these forage plants are limited to these plants only.

The DM values found in the studies on $\mathrm{H}$. microcarpum and P. pabularia are close to $90 \%$, similar to the findings in this study. The DM values reported by Hakan et al. (2009) for H. microcarpum and P. pabularia are $90.58 \%$ and $89.13 \%$, respectively, whereas the DM value reported by Coşkun et al. (2005) for P. pabularia is $91.56 \%$. The CP values of $\mathrm{H}$. microcarpum and P. pabularia found as $9.09 \%$ and $8.84 \%$ in this study are reported to be $8.98 \%$ and $9.41 \%$ by Hakan et al. (2009). The CP value of P. pabularia was reported to be $9.98 \%$ by Coşkun et al. (2005) and $11.44 \%$ by Eilami and Noroozian (1995).

The NDF values of $\mathrm{H}$. microcarpum and $\mathrm{P}$. pabularia obtained in this study are $41.93 \%$ and $42.88 \%$, respectively. The ADF values are $26.84 \%$ and $26.97 \%$, respectively. The NDF values of $H$. microcarpum and P. pabularia reported by Hakan et al. (2009) are $45.38 \%$ and $30.86 \%$, respectively. The ADF values are $27.91 \%$ and $20.01 \%$, respectively. The NDF and ADF values reported by Coşkun et al. (3) for P. pabularia are $34.78 \%$ and $28.45 \%$.

Table.1. Nutrient content of feeds, $\%$

\begin{tabular}{lcccccccc}
\hline \multicolumn{1}{c}{ Forage plants } & DM & Ash & OM & CP & EE & CF & NDF & ADF \\
\hline Dried meadow grass & 92.19 & 8.60 & 83.60 & 8.66 & 2.07 & 41.28 & 61.67. & 33.04 \\
Dried alfalfa & 91.22 & 10.20 & 81.02 & 15.61 & 1.73 & 34.29 & 46.66 & 28.77 \\
H. microcarpum & 91.36 & 8.06 & 83.30 & 9.09 & 2.64 & 37.03 & 41.93 & 26.84 \\
P. pabularia & 91.28 & 7.40 & 83.88 & 8.84 & 1.72 & 40.21 & 42.88 & 26.97 \\
\hline
\end{tabular}

DM: Dry matter, OM: organic matter, CP: crude protein, EE: ether extract, CF: crude fiber, NDF: neutral detergent fiber, ADF: acid detergent fiber 
Table 2. Nutrient digestibility (\%) and energy contents (Mcal/kg DM) of for age plants determined by in vivo method (feeding trial).

\begin{tabular}{lllll}
\hline Forage plants & Dried meadow grass & Dried alfalfa & H. microcarpum & P. pabularia \\
\hline $\mathrm{DM}$ & $66.50 \pm 1.08^{\mathrm{b}}$ & $62.53 \pm 1.43^{\mathrm{c}}$ & $72.81 \pm 1.05^{\mathrm{a}}$ & $67.73 \pm 0.71^{\mathrm{b}}$ \\
$\mathrm{OM}$ & $68.94 \pm 1.01^{\mathrm{b}}$ & $65.81 \pm 1.39^{\mathrm{b}}$ & $75.52 \pm 1.06^{\mathrm{a}}$ & $73.46 \pm 0.63^{\mathrm{a}}$ \\
$\mathrm{CP}$ & $55.68 \pm 2.15^{\mathrm{b}}$ & $71.02 \pm 1.07^{\mathrm{a}}$ & $61.79 \pm 2.75^{\mathrm{b}}$ & $55.32 \pm 1.95^{\mathrm{b}}$ \\
$\mathrm{EE}$ & $48.29 \pm 2.76^{\mathrm{b}}$ & $35.83 \pm 3.70^{\mathrm{c}}$ & $72.18 \pm 1.05^{\mathrm{a}}$ & $45.16 \pm 1.01^{\mathrm{b}}$ \\
$\mathrm{CF}$ & $76.31 \pm 1.23^{\mathrm{a}}$ & $65.41 \pm 1.84^{\mathrm{b}}$ & $78.41 \pm 1.36^{\mathrm{a}}$ & $78.43 \pm 1.13^{\mathrm{a}}$ \\
$\mathrm{NDF}$ & $69.60 \pm 1.16^{\mathrm{a}}$ & $56.09 \pm 2.40^{\mathrm{b}}$ & $65.87 \pm 1.67^{\mathrm{a}}$ & $65.99 \pm 1.03^{\mathrm{a}}$ \\
$\mathrm{ADF}$ & $67.57 \pm 1.10^{\mathrm{a}}$ & $52.13 \pm 2.12^{\mathrm{b}}$ & $65.36 \pm 1.62^{\mathrm{a}}$ & $65.62 \pm 1.63^{\mathrm{a}}$ \\
$\mathrm{DE}$ & $3.04 \pm 0.10^{\mathrm{b}}$ & $2.90 \pm 0.14^{\mathrm{b}}$ & $3.33 \pm 0.11^{\mathrm{a}}$ & $3.24 \pm 0.06^{\mathrm{a}}$ \\
$\mathrm{ME}$ & $2.49 \pm 0.08^{\mathrm{b}}$ & $2.38 \pm 0.12^{\mathrm{b}}$ & $2.73 \pm 0.09^{\mathrm{a}}$ & $2.65 \pm 0.05^{\mathrm{a}}$ \\
$\mathrm{NE}_{\mathrm{L}}$ & $1.57 \pm 0.02^{\mathrm{b}}$ & $1.49 \pm 0.03^{\mathrm{c}}$ & $1.73 \pm 0.03^{\mathrm{a}}$ & $1.68 \pm 0.02^{\mathrm{a}}$ \\
\hline
\end{tabular}

H. microcarpum and P. pabularia were found to have better digestibility than dried meadow grass and dried alfalfa, in terms of the digestibility of OM (Table 2). The OM digestibility of dried meadow grass, dried alfalfa, H. microcarpum and P. pabularia were found to be $68.94 \%, 65.81 \%, 75.52 \%$ and $73.46 \%$, respectively $(p<0.05)$. Therefore, the energy content of the forage plants is also different. DE, ME and NEL values for $\mathrm{H}$. microcarpum and $\mathrm{P}$. pabularia were found to be higher than those for dried meadow grass and dried alfalfa. DE, ME, and NEL values of dried meadow grass, dried alfalfa, $H$. microcarpum and $P$. pabularia were calculated to be $3.04,2.90,3.33$ and $3.24 \mathrm{Mcal} / \mathrm{kg} \mathrm{DM}, 2.49,2.38,2.73$ and $2.65 \mathrm{Mcal} / \mathrm{kg}$ $\mathrm{DM}$, and 1.57, 1.49, 1.73 and $1.68 \mathrm{Mcal} / \mathrm{kg} \mathrm{DM}$, respectively.

In the in vivo trial for digestibility, the digestibility of crude fiber (CF), NDF and ADF, the structural carbohydrates of forage plants, were found to be similar for dried meadow grass, H. microcarpum and P. pabularia, whereas these values are lower for dried alfalfa. In terms of the digestibility of ether extract
(EE), H. microcarpum has the highest and dried alfalfa has the lowest digestibility.

The highest OMD value of the forages obtained through the in vitro method belongs to $\mathrm{H}$. microcarpum (Table 3). OMD values of P. pabularia and dried meadow grass are similar to that of $\mathrm{H}$. microcarpum. OMD value of dried alfalfa was found to be similar to that of dried meadow grass but lower than that of $\mathrm{H}$. microcarpum and P. pabularia. OMD values of dried meadow grass, dried alfalfa, $H$. microcarpum and P. pabularia were found to be $65.99 \%, 58.52 \%, 71.88 \%$ and $68.85 \%$, respectively $(P<0.05)$. The OM digestibility value found by Coşkun et al. (2005) for P. pabularia using the gas production technique is $80.60 \%$. In vitro organic matter digestibility determined by Coşkun et al. (2005) for P. pabularia is higher than the value determined for $P$. pabularia in this study. However, since the values obtained from both studies were found using different in vitro methods, it may be more meaningful to account for this difference by the variation of the methods, rather than the variation of the feeds.

Table 3. Digestibility (\%) and energy contents (Mcal/kg DM) of the for age plants determined by in vitro method (two-stage method)

\begin{tabular}{lllll}
\hline Forage plant & Dried meadow grass & Dried alfalfa & H. microcarpum & P. pabularia \\
OMD & $65.99 \pm 0.98^{\mathrm{ab}}$ & $58.52 \pm 0.84^{\mathrm{b}}$ & $71.88 \pm 4.02^{\mathrm{a}}$ & $68.85 \pm 3.15^{\mathrm{a}}$ \\
$\mathrm{DE}$ & $2.91 \pm 0.43^{\mathrm{ab}}$ & $2.58 \pm 0.35^{\mathrm{b}}$ & $3.17 \pm 0.18^{\mathrm{a}}$ & $3.04 \pm 0.14^{\mathrm{a}}$ \\
$\mathrm{ME}$ & $2.39 \pm 0.07^{\mathrm{ab}}$ & $2.12 \pm 0.06^{\mathrm{b}}$ & $2.60 \pm 0.25^{\mathrm{a}}$ & $2.49 \pm 0.20^{\mathrm{a}}$ \\
$\mathrm{NE}_{\mathrm{L}}$ & $1.50 \pm 0.05^{\mathrm{ab}}$ & $1.31 \pm 0.04^{\mathrm{b}}$ & $1.64 \pm 0.17^{\mathrm{a}}$ & $1.57 \pm 0.13^{\mathrm{a}}$
\end{tabular}

a, $b$ : Values with different letters in the same row found to be different $(\mathrm{P}<0.05)$. OMD: organic matter digestibility, DE: digestible energy, $\mathrm{ME}$ : metabolic energy, $\mathrm{NE}_{\mathrm{L}}$ : net energy lactation. 


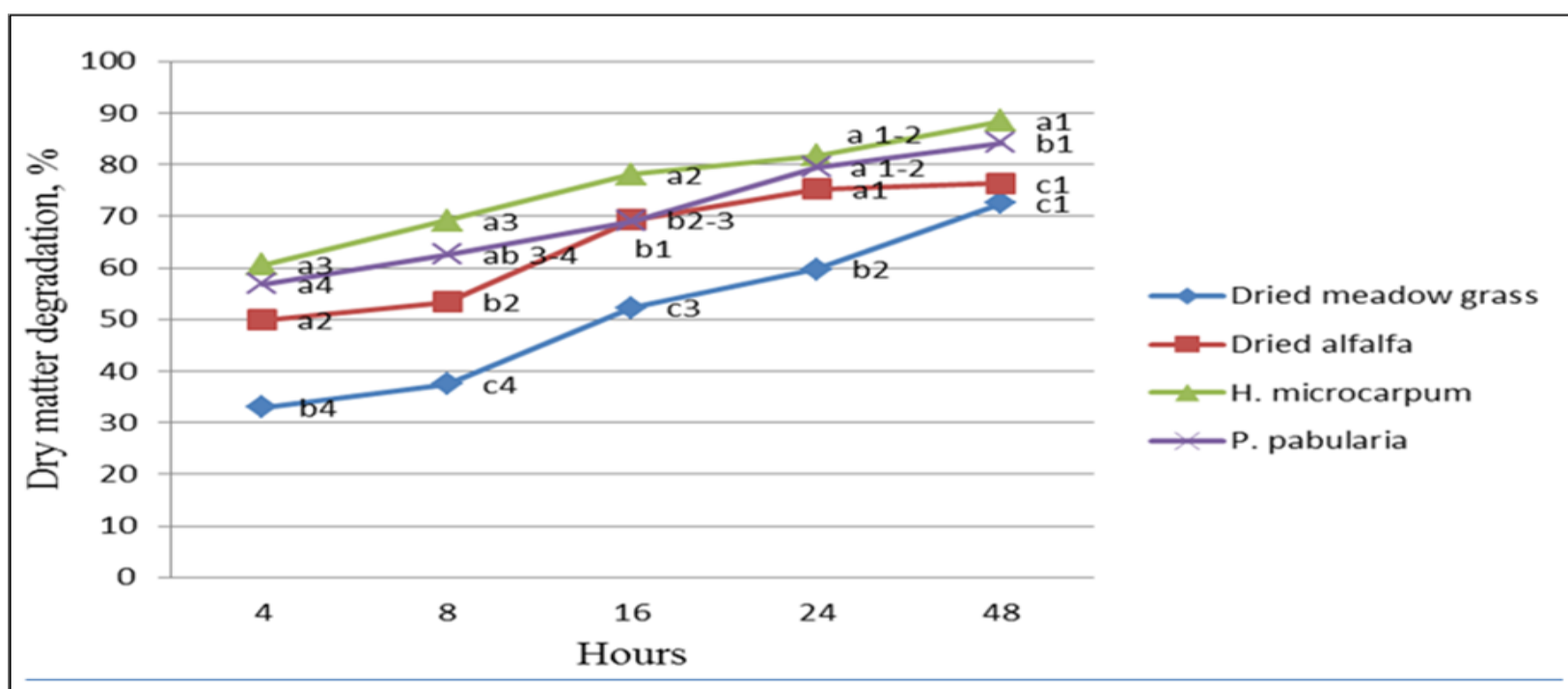

$a, b, c$ : Values with different letters at the same hours were found to be different $(\mathrm{P}<0.05)$. $1,2,3,4$ : Values with different numbers on the same line were found to be different $(\mathrm{P}<0.05)$.

Figure 1. Degradability values for forage plants determined using the in situ (nylon bag) technique, \%

The same situation in the OMD value of forages also applies to the energy values obtained from OMD values. With regard to the energy values of these forages, $\mathrm{H}$. microcarpum and P. pabularia have the highest $D E, M E$ and NEL values. The energy values of dried meadow grass are similar to those of these forage plants. However, the values of dried alfalfa are lower than those of $\mathrm{H}$. microcarpum and P. pabularia, but are similar to those of dried meadow grass. ME values obtained from $\mathrm{H}$. microcarpum and P. pabularia ( 2.60 and $2.49 \mathrm{Mcal} / \mathrm{kg} \mathrm{DM}$, respectively) were found to be lower than the value determined by Coşkun et al. (2005) for P. pabularia (2.906 Mcal/kg DM).

The values for in situ dry matter degradability of the forage plants are given in Figure 1 . It was observed that dried alfalfa, H. microcarpum and P. pabularia were highly degraded after an incubation of four hours, whereas meadow grass showed a slower degradation trend. As for the levels of degradation at the same hour, it was observed that $\mathrm{H}$. microcarpum and P. pabularia had a higher level of degradation at almost every hour, except for their similarity to the degradation of dried alfalfa at the 4th hour. The DM degradation values at the 8th hour, which were determined to be $37.49 \%$ and $53.37 \%$ for dried meadow grass and dried alfalfa, were found to be $69.14 \%$ and $62.50 \%$ for $H$. microcarpum and $P$. pabularia, respectively. The DM degradation values at the end of an incubation of 24 hours, which were determined to be $59.73 \%$ and 75.21 for dried meadow grass and dried alfalfa, were found to be $81.74 \%$ and $79.48 \%$ for $H$. microcarpum and P. pabularia, respectively. At the 48th hour, which was the last incubation in the trial, the dry matter degradation values for dried meadow grass, dried alfalfa, $\mathrm{H}$. microcarpum and P. pabularia were found be $72.45 \%$, $76.36 \%, 88.36 \%$ and $84.21 \%$, respectively $(P<0.05)$. When we examine the rumen degradation of $\mathrm{H}$. microcarpum and P. pabularia between the 4 th and 48th hours, we can see that it follows a very regular trend.

Taking into account the in vivo and in vitro OMD values determined for $\mathrm{H}$. microcarpum and $\mathrm{P}$. pabularia and the energy values calculated, based on those values, these plants were found to have a higher energy value than that of dried alfalfa and dried meadow grass, as they have a high a OMD value. The results show that the energy content of these plants are similar to that of barley. Indeed, Coşkun et al. (2005) report that P. pabularia has a relatively high level of energy for a forage, and this value is comparable to the energy level of barley.

\section{Conclusion}

It is concluded that if cultivated, the high organic matter digestibility and energy content of $\mathrm{H}$. microcarpum and P. pabularia, which grow in the high plateaus of the East Anatolia Region, could be an alternative to the other high-quality forage plants.

\section{Acknowledgements}

The authors would like to express their gratitude to Assoc. Prof. Fevzi ÖZGÖKÇE from the Yuzuncu Yil University Faculty of Science Department of Biology for his contributions to the taxonomic classification of H. microcarpum and and P. pabularia. 


\section{References}

Bratzler, J. W. \& Swift, R. F. (1959). A comparision a nitrogen MAFF. (1975). Energy allowances and feeding systems for and energy determinations on fresh and over- air dried cattle feces . Journal of Dairy Science, 42, 686-691.

Coşkun, B., Gülşen, N., \& Umucalılar, H. D. (2005, September 7-10) Prangos ferulacea (Helis)'nın yem değeri üzerine bir çalışma. III. Hayvan Besleme Kongresi. Adana,Turkey.

Çerçi, ì. H., Erişir, Z., Gürdoğan, F., Seven, I.., Patır, B., Dikici, A., Kılınç, Ü., \& Çiftçi, M. (2011). Taze ot, silaj ve kuru ot şeklinde yedirilen yoncanın kuzularda performans, karkas ve etin duyusal özellikleri üzerine etkisi. Kafkas Üniversitesi Veteriner Fakültesi Dergisi, 17(1), 107-112.

Davis, P. H. (1972). Flora of Turkey and The East Aegean Islands. Edinburgh, UK; University of Edinburgh Press.

Deniz, S.,\& Tuncer, Ş. D. (1995). Bitkisel protein kaynaklarının formaldehit ile muamele edilmesinin rumende kuru madde ve ham protein ile efektif protein yıkılımı üzerine etkisi. Turkish Journal of Veterinary and Animal Sciences, 19(1), 1-8.

Düzgüneş, O., Kesici, T., \& Gürbüz, F. (1983). Istatistik Metodları I. No: 861, Ankara, Turkey; Ankara Üniversitesi Ziraat Fakültesi Yayınları.

Eilami, B., \& Noroozian, H. (1995). Comparison of inclusion in diet of Prangos ferulacea and Medicago sativa on fattening performance and carcas characteristics of Fars native sheep (Karakul). Final Research Report. Fars Research Centre for Natural Resources and Animal Husbandry, Shiraz, Iran.

Hakan, B., Ülker, H., \& Demirel, M. (2009, June 24-26) Van ve çevresinde parzük, kerkol, helizin hayvan yemlemede kullanımı. 6. Zootekni Kongresi, Erzurum, Turkey.

Ishler, V., Heinrichs, J., \& Varga, G. (2000). From feed to milk: Understanding rumen function.

Retrieved from. http://www.dairyweb.ca/Resources/ USWebDocs/RumenFunction.pdf ruminants. Ministery of Agriculture, Fisheries and Food. Department of Agriculture and Fisheries for Scotland, Department of Agriculture for Northern Ireland. Her Majesty's Stationary Office. London.

Marten, G. C., Barnes, \& R. F. (1980). Prediction of energy digestibility of forages with in vitro rumen fermentation and fungal enzyme systems. In W. J., Pigden., C. C., Balch \& M, Graham. (Ed), Standardization of Analytical Methodology for Feed. Ottowa, Canada; International Development Research Centre.

NRC. (1985). Nutrient requirements of sheep. National Washington DC, USA; Academy Press.

NRC. (1989). Nutrient Requirements of Dairy Cattle. 6th rev. ed. Washington DC, USA; National Academy Press.

Öğretmen, T., \& Kılıç, A. (1991). Geviş getirenlerin beslenmesinde kullanılan önemli bazı yemlerin NEL içeriklerinin in vivo ve in vitro yöntemler ile saptanması. PhD thesis, Ege Üniversitesi Fen Bilimleri Enstitüsü, İzmir, Turkey.

Önal, A. G., Şahin, A., \& Kuran, M. (2004, September 1-3). Çakşir (Ferula communis) otunun toklularda üreme fonksiyonları üzerine etkileri, 4. Ulusal Zootekni Kongresi, İsparta, Turkey.

Steel, R. C. D., \& Torrie, J. (1980). Principles and procedures of statistics. A biometrical approach. 2nd ed. , New York, USA; Mc Graw- Hill Book Company.

Tilley, J. M. A., \& Terry, R. A. (1963). A two-stage technique for in vitro digestion of forage. Journal of the British Grassland Society,18,104-111.

Van ES, A. J. H. (1978). Feed evaluation for ruminants. I. The systems in use from May 1977 onwards in The Netherlands. Livestock Production Science, 5, 331-345. 